\title{
ASPEK HUKUM DALAM LINGKUNGAN HIDUP
}

\author{
THAHIR
}

(IAI DDI Polewali Mandar)

\begin{abstract}
ABSTRAK
Masalah lingkungan tidak selesai dengan Undang-Undang dan komitmen untuk melaksanakannya suatu Undang-Undang yang mengandung instrument hukum masih diuji dengan pelaksanaan (uitvoering atau implementation) dan merupakan bagian dari mata rantai pengaturan (regulatory chain) pengelolaan lingkungan. Dalam merumuskan kebijakan lingkungan, Pemerintah lazimnya menerapkan tujuan yang hendak dicapai Kebijakan lingkungan disertai tindak lanjut pengarahan dengan cara bagaimana penetapan tujuan yang dapat dicapai agar diaati masyarakat.
\end{abstract}

\section{Kata Kunci : Aspek Hukum, Lingkungan Hidup.}

\section{PENDAHULUAN}

Lingkungan merupakan sumber daya bagi kehidupan manusia, membawa manfaat dan berperan penting dalam kesehatan, ekonomi dan sosial. Berkaitan dengan memasukkan lingkungan sebagai sumber daya, maka pada prisipnya lingkungan merupakan sumber daya yang dibutuhkan keberadaannya oleh makhluk lainnya, khususnya manusia. Atas dasar untuk kelangsungan hidup hayati, kebutuhan dasar untuk kelangsungan hidup yang menusiawi dan kebutuhan dasar untuk memilih. ${ }^{1}$ Kehidupan manusia tidak akan pernah lepas dari lingkungan. Eksistensi kehidupan manusia sangat tergantung pada lingkungan, lingkungan telah menyediakan secara CumaCuma berbagai kebutuhan bagi manusia yang merupakan syarat mutlak agar manusia dapat mempertahankan kehidupannya. Lingkungan menyediakan air, udara dan sinar matahari yang hal itu adalah merupakan

${ }^{1}$ Supriadi, Hukum Lingkungan di Indonesia), Sinar Grafika, Jakarta 2010, h.5. kebutuhan mutlak manusia. Tanpa air dan udara maka niscaya tidak akan ada kehidupan manusia ${ }^{2} \mathrm{Hal}$ itu dapat dilihat dari keberadaan planet di luar bumi yang tidak memiliki air dan udara, sehingga tidak ada kehidupan di dalam planet tersebut.

Sumber daya alam harus dimamfaatkan dengan baik, sebab jika tidak maka akan menimbulkan gangguan dan kerusakan. Pemerintah lingkungan dari sisi ekonomi dalam bentuk proses produksi, misalnya air, sungai yang dimamfaatkan oleh pabrik untuk mengangkut limbah sisa produksi dan kebutuhan rumah tangga, sudah barang tentu menimbulkan dampak pada kerusakan atau pencemaran lingkungan. Pemamfaatan lingkungan harus dilakukan secara arif dan bijaksana mengingat bahwa sumber daya alam sifatnya ada yang dapat diperbaharui dan ada pula yang tidak dapat diperbaharui misalnya minyak bumi, gas alam, dan bahan tambang lainnya.

${ }^{2}$ A'an Efendi, Hak atas lingkungan hidup yang baik dan sehat serta prosedur pelaksanaannya, Journal Konstitusi Pusat kajian Konstitusi Universitas Jember, Volume III No.2 November 2011, h.31-32 
Awal mula pembahasan permasalahan lingkungan secara global pada tahun 1970-an ditandai dengan konferensi Stockholm tahun 1972 yang membicarakan masalah lingkungan (UN Coference) on the Human Enviroment, UNICHE) yang pada akhirnya ditetapkanlah hari lingkungan hidup sedunia pada tanggal 15 juni. Dari kegiatan tersebut dibentuk sebuah komisi dunia yang disebut dengan Komisi Dunia tentang Lingkungan Hidup dan Pembangunan (World Commission on Environment and Development) tahun 1987 yang kemudian lahir konsep sustainable development kemudian dikuti dengan konferensi PBB di Rio de Janeiro, Brasil tahun 1992.

Di lingkup Asia Tenggara bentuk kesadaran bangsa-bangsa untuk melaksanakan perlindungan dan pelestarian lingkungan hidup diaplikasikan dengan kerja sama, antara lain "tripartite Agreement" dan Deklarasi Manila, hasil dari Deklarasi Manila adalah terbentuknya kerjasama diantara Negara-negara ASEAN pada tahun 1976 yang menghasilkan ASEAN Contingensy Plan dan juga adanya "Rencana Tindak" (Actio Plan). Sasaran utamanya ialah perkembangan dan perlindungan terhadap lingkungan laut dan kawasan pesisir demi kemajuan, kesejatraan, dan kesehatan generasi sekarang dan masa depan.

Dari pembahasan lingkungan secara global tersebut diatas, membuktikan bahwa lingkungan menjadi perhatian (concern) dan isu sntral baik di dunia maupun regional Asia, sebab hal itu menyangkut kelangsungan lingkungan hidup dan seisinya serta hajat hidup orang banyak, karena kelangsungan lingkungan hidup sebagai hak asasi manusia. Dalam Pasal $28 \mathrm{H}$ ayat (1) Undang-Undang Dsar Republik Indonesia Tahun 1945 menegaskan bahwa : "Setiap orang berhak hidup sejahtra lahir dan bathin, bertempat tinggal, dan mendapatkan lingkungan hidup yang baik dan sehat serta berhak memperoleh pelayanan kesehatan."

Pembangunan dalam berbagai aspek kehidupan, tidak selamanya membawa dampak positif bagi kemajuan Negara dan pemerintahan. Justru berkembangnya ilmu pengetahuan dan tehnologi membawa pembangunan ke arah negative. Salah satu instrument pembangunan Negara adalah pembangunan di bidang ekonomi. Upaya pembangunan di bidang ekonomi bergantung pada pertumbuhan ekonomi. Agar pertumbuhan tersebut dapat dikatakan sehat maka harus didukung dengan aktivitas penanaman modal atau investasi. Bentuk investasi yang lebih dikenal adalah berupa properti dan perusahaan. Apalagi adanya birokrasi yang terlalu luwes terhadap proses perizinan usaha, yang tidak mengandalkan penilaian Amdal, sehingga persoalan lingkungan hidup menjadi terabaikan. Akibatnya adalah menimbulkan dampak negative terhadap lingkungan yakni pencemaran dan kerusakan lingkungan. Melihat dampak tersebut maka diperlukan adanya instrument penegakan hukum di bidang lingkungan melalui pengaturan Hukum Lingkungan.

Contoh Kasus : Perusahaan Pembakaran Arang di Palippis, Kecamatan Campalagian PT. Hanman Siama Seang, merupakan Perusahaan Modal Asing (PMA) telah beroperasi selama 6 Tahun tanpa memiliki Perizinan ( Berita Radar Sul-Bar, Tribun Polman Tanggal 18 Juli 2017) 


\section{KENDALA PENEGAKAN HUKUM LINGKUNGAN.}

Menegakkan hukum lingkungan dewasa ini memang dihadapkan sejumlah kendala. Pertama, masih terdapat perbedaan persepsi antara aparatur penegak hukum dalam memahami dan memaknai peraturan perundang-undangan yang ada. Kedua, biaya untuk menangani penyelesaian kasus lingkungan hidup terbatas. Ketiga, membuktikan telah terjadi pencemaran atau perusakan lingkungan bukanlah pekerjaan mudah. Era reformasi dapat dipandang sebagai peluang yang kondusif untuk mencapai keberhasilan dalam penegakan hukum lingkungan.

Perlu exit strategy sebagai solusi penting yang harus diambil oleh pemegang policy dalam menyelamatan fungsi lingkungan hidup. Pertama, mengintensifkan keterpaduan dan koordinasi antar sector terkait dalam pengelolaan sumber daya alam dan lingkungan hidup. Kedua, adanya saksi yang memadai (enforceability) bagi perusahaan yang membandel dalam pengelolaan limbah sesuai dengan aturan yang berlaku. Jika ada indikasi tindak pidana, aparat penegak hukum dapat menindak tegas para pelaku/penanggung jawab kegiatan seperti diatur dalam Pasal 4148 UU 23 Tahun 1997 tentang Pengelolaan Lingkungan Hidup. Ketiga, adanya partisipasi publik, transparansi, dan demokratisasi dalam pengelolaan sumber daya alam dan lingkungan hidup patut ditingkatkan. Pengelolaan lingkungan hidup akan terkait tiga unsur, yaitu pemerintah, pengusaha dan masyarakat. Pada gilirannya dalam pengelolaan lingkungan hidup setiap orang mempunyai hak yang sama untuk menikmati lingkungan hidup yang baik dan sehat.

\section{MENUMBUHKAN KESADARAN HUKUM LINGKUNGAN.}

Menurut Soerjono Soekanto, Kesadaran hukum masyarakat menyangkut factor-faktor apakah suatu ketentuan hukum diketahui, dimengerti, ditaati dan dihargai. Apabila masyarakat hanya mengetahui adanya suatu ketentuan hukum, maka taraf kesadaran hukumnya lebih rendah daripada apabila mereka memahaminya dan seterusnya. Kesadaran hukum meliputi berbagai aspek kehidupan dan tingkat kesadarannya bisa berbeda-beda tergantung tingkat aplikasi factor-faktor diatas, selain itu, kesadaran hukum juga ditentukan oleh sudut pandang masing-masing individu dalam melihat "Hukum".

Kesadaran hukum lingkungan, baik itu pelestarian maupun pengelolaannya, pada hakikatnya manusia harus memiliki kesadaran hukum yang tinggi, karena manusia memiliki hubungan sosiologis maupun biologis secara langsung dengan lingkungan hidup dimana dia berada, sejak dia lahir sampai meninggal dunia. Namun kesadaran hukum masih dipengaruhi oleh beberapa faktor, seperti ekonomi, sosial, budaaya, dan lain-lain. Oleh karena itu, perlu adanya upaya-uapaya straegis untuk menumbuhkan kesadaran hukum tersebut, baik dari sisi mental manusianya maupun dari segi kebijakan. Sinergi keduanya penting, karena kesadaran hukum itu ada yang tumbuh karena memang sesuai dengan nilai yang dianutnya.

Misalnya orang yang suka dengan hidup bersih, maka ia tidak akan membuang sampah sembarangan. Kesadaran hukum juga dapat tumbuh karena takut dengan sanksi yang dijatuhkan. Kesadaran semu inilah yang banyak dimiliki oleh masyarakat kita. Lepas dari penyebab kesadaran hukum itu muncul, yang berbahaya adalah apabila kesadaran hukum itu telah ada namun 
kemudian menurun bahkan hilang karena factor eksternal, seperti penegakan hukum yang tidak tegas dan tebang pilih. Hal ini akan menurunkan kesadaran hukum masyarakat dan menimbulkan kesadaran hukum tidak cukup dengan menuntut masyarakat, tetapi juga harus disertai dengan tauladan dan penegakan hukum.

Manusia, baik kedudukannya sebagai anggota masyarakat, sebagai pelaku usaha, sebagai aparat penegak hukum, maupun sebagai pembuat/pengambil kebijakan, harus memiliki kesadaran hukum lingkungan meskipun secara bertahap, dari sekedar mengetahui sampai dengan mentaati dan menghargai berbagai ketentuan hukum lingkungan yang ada.

Berkaitan dengan faktor-faktor kesadaran hukum sebagaimana disebutkan diatas, untuk hukum lingkungan, ada beberapa masalah yang perlu dicermati, yaitu : Pertama, "Mengetahui", secara yuridis, setelah UU disahkan, sejak itu pula muncul asumsi bahwa masyarakat dianggap mengetahuinya. Asumsi ini terealisasi apabila pasca diundangkan ada aktivitas sosialisasi yang tepat dan kontinyu. Bila tidak, maka dapat dihitung berapa jumlah masyarakat Indonesia yang mengetahui tentang peraturan tersebut dan jumlahnya dipastikan tidak akan menyentuh masyarakat kalangan bawah, tidak hanya di desa tetapi juga diperkotaan. Akibatnya tidak heran bila ada kegiatan usaha yang tidak memiliki atau bahkan tidak mengetahui perlunya AMDAL.

Kedua, "Mengerti", masyarakat tidak cukup hanya sekedar mengetaui saja, tetapi juga harus memahami isi peraturan, seperti apa tujuan dan mamfaat dikeluarkannya peraturan tersebut. Hukum lingkungan tentunya bertujuan agar proses pembangunan tidak merusak lingkungan. Oleh karena itu diperlukan adanya aturan AMDAL dan perizinan. Adanya aturan ini hendaknya tidak menjadi beban bagi pelaku usaha dan lahan korupsi bagi oknum birokrasi/aparat hukum, tetapi sebagai upaya preventif bersama aagar kegiatan usaha tidak merusak lingkungan.

Ketiga "Mentaati", setelah mengetahui dan memahami, maka diharapkan dapat mentaati. Namun hal ini masih dipengaruhi oleh beberapa factor. Bagi pihak yang merasa kepentingannya sama, maka biasanya akan langsung mentaati. Apabila tidak, maka masih ada proses berfikir, bahkan mencari celah bagaimana "menghindari" atau "mensiasatinya".

Keempat "Menghargai", ketika seseorang telah mentaati, maka sikap menghargai suatu peraturan hukum lingkungan itu akan muncul bersamaan dengan kesadaran hukumnya bahwa hukum tersebut memang wajib untuk ditaati demi kepentingan dirinya, masyarakat dan dalam upaya mencegah kerusakan lingkungan. Proses menumbuhkan kesadaran hukum lingkungan diatas, jangan sampai terjebak dengan kata "Lingkungan" saja, sehingga hanya UU No. 23 tahun 1997 tentang Pengelolaan Lingkungan Hidup (UUPLH) saja yang dipahami masyarakat, tetapi juga UU lain yang berkaitan dengan lingkungan hidup, seperti UU tentang Perikanan, Benda Cagar Budaya, Pertambangan, ZEE, Perindustrian, Konsevasi Sumber Daya Alam Hayati dan Ekosistemnya, dan Pelayaran. Karena lingkungan hidup itu meliputi tanah, air, udara, ruang angkasa, termasuk manusia dan perilakunya. UU PLH pada dasarnya merupakan UU induk atau Payung "umbrella Act" dibidang lingkungan hidup bagi semua UU tersebut.

Upaya untuk menumbuhkan kesadaran hukum masyarakat dalam pelestarian lingkungan dapat dilakukan dengan beberapa cara yaitu : Pertama 
meningkatkan program sosialisasi dari tingkat pusat sampai ke desa-desa, khususnya berkaitan dengan hak dan kewajiban serta berbagai permasalahan riil yang dihadapi oleh masyarakat, seperti prosedur AMDAL, perizinan dan dampak positif dan negative apabila prosedur tersebut tidak dilakukan. Kedua : Meningkatkan kesadaran hukum (mental) semua pihak, Ketiga : Menindak tegas oknum pemerintah/aparat yang menyalagunakan wewenangnya dan menindak tegas pelaku perusakan/pencemaran lingkungan tanpa tebang pilih sehingga masyarakat percaya dengan upaya penegakan hukum lingkungan.

Keempat : Memangkas proses birokrasi yang panjang dan berbelit-belit. Kelima : semakin meningkatkan kualitas dalam pemberian penghargaan dibidang lingkungan, khususnya kriteria pembangunan berwawasan lingkungan, baik ditingkat nasional maupun daerah-daerah.

Keenam : menghinddari penggunaan sarana hukum pidana dalam penegakan hukum lingkungan yang masih dapat menggunakan sarana hukum lain yang lebih efektif. Contohnya Perda tentang pembuangan sampah disembarang tempat dengan sanksi pidana kurungan dan denda yang tinggi yang ternyata tidak efektif.

Tumbuhnya kesadaran hukum lingkungan diharapkan dapat mendukung terwujudnya slogan "Pembangunan Berwawasan Lingkungan" menjadi kenyataan dan tidak hanya sekedar menjadikannya sebagai visi dan misi pembangunan saja.

\section{HUKUM LINGKUNGAN \\ (MANIFESTASI UNDANG-UNDANG \\ NO. 32 TAHUN 2009 TENTANG \\ PERLINDUNGAN DAN \\ PENGELOLAAN LINGKUNGAN).}

UU No. 32 Tahun 2009 tentang Perlindungan dan Pengelolaan Lingkungan Hidup yang selanjutnya disingkat UUPPLH adalah domainya hukum lingkungan di Indonesia. Manifestasi UUPPLH menunjukkan perihal hukum dan lingkungan. Hukum Lingkungan dari dua buah kosakata Hukum dan Lingkungan diuraikan dalam manifest UU No. 32 Tahun 2009 sebagai berikut:

1) Hukum

Hukum tersebut ditempatkan sebagai

a. Mengatur; dan

b. Pengamanan.

Sebagai mengatur konsepsinya terletak pada wewenang pada wewenang peraturan perundangundangan dalam sistem pemerintahan yang berdasarkan paham Negara hukum yang diarahkan pada legitimasi kekuasaan untuk mengatur wilayah. Mengacu pada pandangan Hans Kelsen: Bahwa suatu sistem hukum adalah suatu hierarkis dari hukum di mana suatu ketentuan hukum tertentu bersumber pada ketentuan hukum lainnya yang lebih tinggi. Sebagai ketentuan yang lebih tinggi adalah Groundnorm atau norma dasar yang bersifat hipotesis. Ketentuan yang lebih rendah adalah lebih konkert dari pada ketentuan yang lebih tinggi. ${ }^{1}$ Dalam buku General Theory of Law and State dijelaskan bahwa teori ini tidak boleh dipengaruhi oleh motif-motif atau maksud-maksud dari para pejabat pembuat hukum atau oleh keinginan atau kepentingan individu-individu berkenaan dengan maksud ini, keinginan dan kepentingan ini, dimanifestasikan dalam materi hukum yang dihasilkan oleh proses 
pembuatan hukum. Apa yang dijumpai dalam isi norma hukum positif tidak bisa memasuki konsep hukum. Teori umum tentang hukum diarahkan pada analisis structural terhadap hukum positif bukan pada penjelasan psikologis dan ekonomis berkenaan dengan kondisikondisinya, atau penilaian moral atau politik berkenaan dengan tujuantujuannya. ${ }^{3}$

Sebagai pengamanan konsepsinya dikemukakan oleh Jeremy Bentham ${ }^{3}$ sebuah teori untuk menerapkan prinsip-prinsip umum dari pendekatan "utilitarian" kedalam kawasan hukum. Menurut Bentham: Tujuan akhir dari perundangundangan adalah untuk melayani kebahagiaan yang paling besar dari sejumlah terbesar rakyat.

Prinsip dari aliran Utilitarianisme adalah: "Manusia akan melakukan tindakan untuk mendapatkan kebahagiaan yang sebesar-besarnya dan mengurangi penderitaan. Betham mencoba menerapkannya di bidang hukum. Atas dasar ini, baik buruknnya suatu perbuatan diukur apakah perbuatan itu mendatangkan kebahagiaan atau tidak. Demikianpun dengan perundang-undangan, baik buruknya ditentukan pula oleh ukuran tersebut di atas. Jadinya undangundang yang banyak memberikan kebahagiaan paa bagian terbesar masyarakat akan dinilai sebagai undang-undang yang baik. ${ }^{4}$

2) Lingkungan

3 H. Lili Rasjidi \& Ira Thania Rasjidi. 2004. Dasar-Dasar Fislsafat Dan Teori Hukum. Bandung: PT. Citra Aditya Bakti. Hal. 61.

4 Hans Kelsen, 2006, Teori Umum Tentang Hukum dan Negara, (Terj.), Raisul Muttaqien, Cet. I. Nusamedia \& Nuansa, Bandung, Hal. vi.
Pada Pasal 1 angka 1 dibunyikan sebagai berikut:

Lingkungan hidup adalah kesatuan ruang dengan semua benda, daya, keadaan, dan makhluk hidup, termasuk manusia dan prilakunya, yang memengaruhi alam itu sendiri, kelangsungan perikehidupan dan kesejahteraan manusia serta makhluk hidup lain.

$\begin{array}{rcr}\text { Dengan } & \text { demikian } & \text { yang } \\ \text { dimaksudkan } & \text { dengan } & \text { "hukum }\end{array}$ lingkungan" adalah sebuah deskripsi dari prinsip mengatur dan mengamankan terhadap lingkungan hidup sebagaimana pengertian diamksud dalam Pasal 1 angka 1.

Menifestasi selanjutnya adalah sebagai berikut :

1. Perlindungan dan pengelolaan lingkungan (Peraturan dari UU 32 Tahun 2009)

Pasal 1 angka 2 berbunyi :

Perlindungan dan pengelolaan lingkungan hidup adalah upaya sistematis dan terpadu yang dilakukan untuk melestarikan fungsi lingkungan hidup dan mencegah terjadinya pencemaran, pemamfaatan, pengendalian, pemeliharaan, pengawasan, dan penegakan hukum.

2. Fungsi hukum lingkungan.

Fungsi hukum lingkungan adalah mengatur dan melindungi ekosistem sebagaimana dibunyikan pada : Pasal 1 angka 4 berbunyi :

Ekosistem adalah tatanam unsure lingkungan hidup yang merupakan kesatuan utuh menyeluruh dan saling mempengaruhi dalam 
membentuk keseimbangan, stabilitas, dan produktivitas lingkungan hidup.

3. Ekosistem.

Pasal 1 angka 5 berbunyi :

Ekosistem adalah tatanan unsure lingkungan hidup yang merupakan kesatuan utuhmenyeluruh dan saling mempengaruhi dalam membentuk keseimbangan, stabilitas, dan produktivitas lingkungan hidup.

Dalam memahami hukum lingkungan yang menjadi focus utama adalah ekosistem. Hukum lingkungan hadir untuk melindungi ekosistem dari ancaman zat-zat yang dapat merusak. Ukuran yang di pergunakan dalam menentukan ekosistem pada keadaan normal adalah "baku mutu lingkungan". Baku mutu lingkungan dibunyikan pada Pasal 1 angka 13. Baku mutu lingkungan hidup adalah ukuran batas atau kadar makhluk hidup, zat, enegi, atau komponen yang ada harus ada dan/atau unsure pencemaran yang ditanggung keberadaannya dalam suatu sumber daya tertentu sebagai unsure lingkungan hidup. Keterkaitan adalah baku mutu lingkungan merupakan tolak ukur untuk penentuan terjadinya pencemaran lingkungan hidup.

\section{ASPEK HUKUM PERDATA DALAM PERLINDUNGAN DAN PENGELOLAAN LINGKUNGAN HIDUP.}

Tujuan penegakan hukum lingkungan melalui mekanisme hukum perdata lebih berorientasi untuk memberikan perlindungan hukum terhadap lingkungan maupun si korban yang menderita kerugian sebagai akibat pencemaran atau perusakan lingkungan hidup. Hukum perdata dapat memberikan kemungkinan untuk mengajukan gugatan ganti kerugian atas pencemaran lingkungan terhadap pihak yang menyebabkan timbulnya pencemaran/kerusakan lingkungan hidup, yang biasanya dilakukan melalui gugatan perbuatan melawan hukum.

Dalam konteks Perbuatan Melawan Hukum dalam sengketa lingkungan hidup di Indonesia dikenal Asas Tanggung Jawab Mutlak. Asas tanggung jawab mutlak (strict liability) merupakan salah satu jenis pertanggung jawabab perdata (civil liability). Pertanggung jawaban perdata dalam konteks penegakan hukum lingkungan merupakan instrument hukum perdata untuk mendapatkan ganti kerugian dan biaya pemulihan lingkungan akibat pencemaran dan atau perusakan lingkungan. Pertanggung jawaban tersebut mengenal 2 (dua) jenis pertanggung jawaban :

1. Pertanggung jawaban yang mensyaratkan adanya unsure kesalahan (fault based liability);

2. Pertanggung jawaban mutlak/ketat (strict liability) suatu pertanggung jawaban tanpa harus dibuktikan adanya unsure kesalahan (fault).

Konsep pertama tersebut dikenal sebagaimana yang termuat dalam ketentuan Pasal 1365 KUHPerdata yaitu perbuatan melawan hukum. Perbuatan melawan hukum berdasarkan Pasal 1365 KUH Perdata mensyaratkan penggugat membuktikan adanya unsure kesalahan 
(fault). Mengandalkan unsure kesalahan dalam konteks pesatnya perkembangan keilmuan dan tehnologi sering-kali menimbulkan kesulitan dalam memprediksi risiko yang timbul dari suatu kegiatan (industri). Melihat keterbatasan dari fault based liability ini maka mungkin terjadi timbulnya pencemaran atau perusakan lingkungan tanpa dapat dikenakan pertanggung jawaban. fault based liability juga memungkinkan pencemar atau perusak lingkungan terbebas dari pertanggung jawaban perdata apabila ia dapat membuktikan bahwa ia telah melakukan upaya maksimal pencegahan pencemaran melalui pendekatan. Analisis Mengenai Dampak Lingkungan (dengan melaksanakan RKL dan RPL secara konsisten) oleh karena itu, sejak adanya UU No. 23 Tahun 1997 tentang Pengelolaan Lingkungan Hidup, Azas yang dianut adalah tanggung jawab mutlak (Strict Liability), begitu juga dalam Undang-Undang No. 32 Tahun 2009 Tentang Perlindungan dan Pengelolaan Lingkungan Hidup yang menganut azas ini, sehingga tidak perlu dibuktikan adanya kesalahan, tetapi cukup membuat potensi tersebut terjadi, maka dapat dijadikan dasar gugatan.

\section{ASPEK HUKUM PIDANA DALAM KONTEKS PERLINDUNGAN DAN PENGELOLAAN LINGKUNGAN} HIDUP.

Penegakan hukum di bidang lingkungan menurut Keith Hawkin, sebagaimna dikutip oleh Koesnadi Hardjasoemantri pada dasarnya dapat dilihat dari dua strategi yang berkarakter yakni pembenahan peraturan dan pemberian sanksi. Oleh karena itu merupakan suatu keharusan dalam pengaturan mengenai lingkungan dimasukkan ketentuan pidana di dalamnya agar penegakan hukum lingkungan itu sendiri dapat berjalan secara efektif.

Pada hakekatnya eksistensi hukum pidana dalam Undang-Undang No. 32 Tahun 2009 Tentang Perlindungan Dan Pengelolaan Lingkungan Hidup adalah bertujuan untuk mempertahankan eksistensi lingkungan kepada fungsi keberlanjutannya. Pada esensinya, hukum pidana merupakan sarana represif, yakni serangkaian pengaturan yang ditujukan untuk mengendalikan peristiwa-peristiwa negatif, supaya pada berikutnya kembali kepada keadaan semula. Berkaitan dengan fungsinya yang represif, hukum pidana hendaknya dibantu oleh sejumlah kebijakan pengenaan perangkat, yang berperan kepada arah perlindungan lingkungan.

Pengaturan tindak pidana lingkungan diatur dalam Pasal 98 sampai dengan Pasal 120 Undang-Undang No. 32 Tahun 2009 Tentang Perlindungan dan Pengelolaan Lingkungan Hidup. Ancaman pidananya dapat berupa pidana penjara, dendan dan pidana tambahan atau tata tertib. Penegakan hukum pidana dalam Undang-Undang No. 32 Tahun 2009 Tentang Perlindungan Dan Pengelolaan Lingkungan Hidup memperkenalkan ancaman hukuman minimum di samping maksimun, perluasan alat bukti, pemindanaan bagi pelanggaran baku mutu, keterpaduan penegakan hukum pidana, dan pengaturan tindak pidana korporasi. 
Mekanisme penegakan hukum pidana lingkungan meliputi beberapa proses, dan setiap proses akan tetap mengacu kepada ketentuan-ketentuan hukum, baik yang diatur dengan hukum pidana formiil (Hukum acara pidana) maupun hukum pidana materiil, seperti diketahui penegakan hukum lingkungan dapat dibagi ke dalam 3 (tiga) tahapan pokok, yakni : 1. Tindakan pre-intive, 2. Tindakan preventif, 3. Tindakan represif. Tindakan Pre-entive, yakni tindakan antisipasi yang bersifat mendeteksi secara lebih awal berbagai factor korelasi kriminogen, yakni faktorfaktor yang memungkingkan kerusakan dan pencemaran lingkungan. Dengan deteksi atau factor kriminogen ini dapat dilakukan pencegahan dan tidak terjadi ancaman factual terhadap lingkungan.

Tindakan Prepektif adalah serangkaian tindakan nyata yang bertujuan untuk mencegah perusakan atau pencemaran lingkungan , misalnya pengawasan yang kontinuterhadap pabrik-pabrik , pengawasan-pemngawasan hukum lingkungan bersipat responsive terhadap pengaduan masyarakat, para polisi kehutanan mengawasi pencurian kayu dan penebangan liar,atau pejabat instansi sektoral lingkungan menegur dan member peringatan kepada pihak-pihak yang melakukan gejala tidak baik bagi sistem lingkungan. Sedangkan Tindakan represif adalah serangkaian tindakan yang dilakukan oleh petugas hukum melalui proses hukum pidan, karena perbuatan yang dilakukan oleh pelaku merusak dan mencemari lingkungan.

Proses penegakan hukum pidana yang diatur dalam Undang-Undang No.
32 Tahun 2009 tentang Perlindungan dan Pengelolaan Lingkungan Hidup, meliputi tahap-tahap sebagai berikut :

1. Tahap penyelidikan

2. Tahap Penyidikan

3. Tahap eksekusi atau penuntutan,

4. Tahap peradilan

Dalam melakukan proses untuk setiap tahap penegakan hukum pidana ialah ketentuan-ketentuan hukum acara. Sumber pokok hukum acara pidana adalah KUHAP dan disamping itu didapat dari ketentuan-ketentuan khusus di dalam undang-undang yang relevan, termasuk Undang-Undang No. 32 Tahun 2009 Tentang Perlindungan Dan Pengelolaan Lingkungan Hidup. Pejabat penyidik terhadap tindak pidana lingkungan menurut Pasal 94 UUPPLH, terdiri dari kalangan kepolisisan dan pejabat pegawai negeri sipil (PPNS) di lingkungan kantor menteri lingkungan hidup. Dalam Pasal 94 ayat (2) UUPPLH. Diatur penyidik pejabat pegawai negeri sipil berwenang :

1. Melakukan pemeriksaan atas kebenaran laporan atau keterangan berkenaan dengan tindak pidana di bidang perlindungan dan pengelolaan lingkungan hidup.

2. Melakukan pemeriksaan terhadap setap orang yang diduga melakukan tindak pidana dibidang perlindungan dan pengelolaan lingkungan hidup.

3. Meminta keterangan dan bahan bukti dari setiap orang berkenaan dengan peristiwa tindak pidana di bidang perlindungan dan pengelolaan lingkungan hidup.

4. Melakukan pemeriksaan atas pembukuan, catatan dan dokumen lain berkenaan dengan tindak pidana 
dibidang perlindungan dan pengelolaan lingkungan hidup.

5. Melakukan pemeriksaan di tempat tertentu yang diduga terdapat bahan bukti, pembuktian catatan, dan dokumentasi lain.

6. Melakukan penyitaan terhadap bahan dan barang hasil pelanggaran yang dapat dijadikan bukti dalam perkara tindak pidana dibidang perlindungan dan pengelolaan lingkungan hidup.

7. Meminta bantuan ahli dalam rangka pelaksanaan tugas penyidikan tindak pidana dibidang perlindungan dan pengeloaan lingkungan hidup.

8. Menghentikan penyidikan.

9. Memasuki tempat tertentu, memotret, dan/atau membuat rekaman audio visual.

10. Melakukan penggeledahan terhadap badan, pakaian, ruangan, dan/atau tempat lain yang diduga merupakan tempat dilakukannya tindak pidana, da/atau

11. Menangkap dan menahan pelaku tindak pidana.

Pennuntutan dilakukan oleh penuntut umum dari kejaksaan, dengan melimpahkan berkas perkara tersebut ke pengadilan untuk kemudian dimintakan supaya diperiksa dan diputus oleh pengadilan. Pengadilan terdiri dari hakim dan penitera, dihadiri oleh penuntut umum dan tardakwa dan kuasanya, melakukan proses peradilan untuk menerima, memeriksa dan memutus perkara tersebut sesuai asasasas peradilan yang diatur oleh peraturan perundang-undangan.

\section{PELAKSANAAN HUKUM ADMINISTRASI DALAM PERLINDUNGAN DAN PENGELOLAAN LINGKUNGAN HIDUP.}

Penerapan hukum administrasi dalam konteks perlindungan dan pengelolaan lingkungan hidup mempunyai fungsi sebagai instrument pengendalian, pencegahan, dan penanggulangan perbuatan yang dilarang oleh ketentuanketentuan lingkungan hidup. Melalui sanksi administrasi dimaksudkan agar perbuatan pelanggaran itu dihentikan, sehingga sanksi administrasi merupakan instrument yuridis yang bersifat preventif dan represif non-yustisial untuk mengahiri atau menghentikan pelanggaran ketentuan-ketentuan yang tercantum dalam persyaratan perlindungan dan pengelolaan lingkungan hidup.

Selain bersifat represif, sanksi administrasi juga mempunyai sifat reparatoir, artinya memulihkan keadaan semula, oleh karena itu penyalagunaan sanksi administrasi dalam penegakan hukum lingkungan penting bagi upaya pemulihan media lingkungan yang rusak atau tercemar. Berbeda dengan sanksi perdata maupun sanksi pidana, penerapan sanksi administrasi oleh pejabat administrasi dilakukan tanpa harus melalui proses pengadilan (non yustisial) sehingga penerapan sanksi administrasi relative lebih cepat dibandingkan dengan sanksi lainnya dalam upaya untuk menegakkan hukum lingkungan. Yang tidak kalah pentingnya dari penerapan sanksi administrasi ini adalah terbuka ruang 
dan kesempatan untuk partisipasi masyarakat.

Penegakkan hukum administrasi dibidang perlindungan dan pengelolaan lingkungan hidup didasarkan atas dua instrument penting, yaitu pengawasan dan penerapan sanksi administrative, pengawasan dilakukan untuk mengetahui tingkat ketaatan penanggung jawab usaha dan/atau kegiatan terhadap ; Izin Lingkungan, 2. Paksaan Pemerintah, 3. Pembekuan Izin Lingkungan dan/atau Izin Perlindungan dan Pengelolaan Lingkungan Hidup, 4. Pencabutan Izin Lingkungan dan/atau Izin Perlindungan dan Pengelolaan Lingkungan Hidup.

\section{PENUTUP}

Kesimpulan

A. Kesimpulan

Masyarakat Indonesia dalam kenyataannya lebih akrab dengan lingkungan alamnya daripada penerapan tekhnologi. Perkembangan tekhnologi yang mengelola sumber daya alam harus memberikan mamfaat yang sebesarbesarnya bagi masyarakat rakyat, dengan tetap memperhatikan keseimbangan dan kelestariannya sehingga tetap bermamfaat bagi generasi-generasi mendatang. Dengan memperhatikan kualitas alam, sosial, budaya, dan ekonomi sebagai komoditi masyarakat setempat yang tersubsistem. Hanya tindakan manusia yang membuat seolah-olah mampu menguasai alam sehingga hamper semua lingkungan hidup sudah tersentuh oleh kehidupan manusia. Penerapan hukum lingkungan dapat dilakukan dengan pemberian sanksi yang berupa sanksi administrasi.
B. Saran

Saran saya kepada Pemerintah untuk kiranya lebih meningkatkan lagi dalam hal penegakan hukum lingkungan di Negara kita ini, sekiranya apa yang sudah diterbitkan dalam Undangundang dapat ditegakkan dengan tegas berdasarkan peraturan perundang-undangan tersebut.

Kepada masyarakat Negeri ini, khususnya masyarakat Polewali Mandar maupun Mahasiswa/I sekiranya dapat menjaga dan melestarikan lingkungan sebagaimana yang sudah diatur di dalam undang-undang, dan agar sekiranya ketidaktahuan masyarakat terhadap mekanisme penanganan tindak pidana lingkungan di sosialisasikan.

\section{DAFTAR PUSTAKA.}

1. Faisal, S.H., M.H., 2016, Hukum Lingkungan, Pengaturan Limbah dan Paradigma Industri Hijau, Penerbit CT X, Gejaya, Yogyakarta

2. Dr. H. Bachrul Amiq, S.H., M.H., 2016, Hukum Lingkungan, Sanksi Administrasi dalam Penegakan Hukum Lingkungan, Penerbit Laksbang Grafika, Minomartani Ngaglik Sleman, Yogyakarta,

3. A'an Efendi, 2011, Hak atas lingkungan hidup yang baik dan sehat serta prosedur pelaksanaannya, Journal Konstitusi Pusat kajian Konstitusi Universitas Jember.

4. Supriadi, 2010, Hukum Lingkungan di Indonesia, Penerbit Sinar Grafika, Jakarta 